\title{
INDONESIA - MALAYSIA RELATIONS FROM THE PERSPECTIVE OF MARITIME HISTORY OF THE STRAITS OF MALACCA
}

\author{
Mhd. Nur, M.S. \\ Faculty of Humanities \\ University of Andalas \\ Padang, Indonesia \\ (mhdnur@hum.unand.ac.id) \\ DOI: https://doi.org/10.22452/jati.vol23no1.4
}

\begin{abstract}
Malays inhabit Indonesia and Malaysia. They are connected with each other since time immemorial. The separation of Malays in two countries offers an interesting relationship. This review article maintains that the Strait of Malacca- a narrow stretch of water- does not separate Indonesia and Malaysia, but it connects the island of Sumatra (Indonesia) and the Malay Peninsula through social, cultural, and economic practices. The waters of the Straits of Malacca acted like glue between Indonesia and Malaysia. The waters of the Strait of Malacca are relatively narrow, but the area is crowded by international merchant ships from the West and East. The traders of the archipelago and foreign traders gather to form a unique hub of maritime social, economic, political, social, and cultural activities. The Strait of Malacca is a hub of civilization that has proven that there is no separation between Indonesian and Malaysian cultures. Cultural diffusion in the Strait of Malacca is the unique cultural mixture in the world. The review finds that various cultural factors influence the narrow region. Among some of the ethnic Malays who trade in the Straits of Malacca are Minangkabau Malay, Aceh, Bugis, Jambi, Deli, Semang, and Senoi.
\end{abstract}

Keywords: maritime culture, multicultural, ethnicity, history, Strait of Malacca

\section{Introduction}

The Straits of Malacca is a well known maritime area in the history of shipping and trade. It is located between the island of Sumatra (Indonesia) and the Malay Peninsula. It is a hub of Asian trade. Many studies are conducted on the Strait of Malacca as a trade conduit. Cultural activities and maritime trade are 
the outcomes of a meeting between people of both sides and also people who transit through it. Meetings often occur in the port areas located along the Strait of Malacca, which has encouraged the formation of several ports in the vicinity with all forms of activities. Different aspects are found in the Strait of Malacca Strait maritime culture. Development taking place in a port or harbor on the west coast of Peninsular Malaysia would be different from the events that occurred at ports along the east coast of Sumatra or the other archipelago areas. Even life and culture between ports located on the east coast of Sumatra are entirely different than the ports located in the southern part of Sumatra. Also, the same kind of difference is witnessed along the west coast of the Malay Peninsula. A port had a distinct nature of culture and practices, which greatly depended on where it is located. Many of the activities in the port areas are determined by windstorm season, provision of open or closed areas to foreign traders, production of various items/commodities, provision of port facilities, wisdom performed by syahbandar, the role of local leaders, and so on (Nur, 2015, p. 12).

In general, some researchers have studied the harbor. They saw the role of the port and the economic policies that are run by local authorities or the colonial government in the past. There is also another perspective to see the port as a place of trade, shipping, and gates out for delivery of commodities from the hinterland. Among the researchers were Muhammad Nur, Sutjipto Tijptoatmodjo, J. Kathhirithamby-Wells, Heather Sutherland, Edward L. Poelinggomang, and others.

According to Muhammad Nur (2015), during the $19^{\text {th }}$ century until the mid-20 $0^{\text {th }}$-century trading port of Sibolga had become more crowded as compared to the existing port on the western coast of Sumatra Island. The city located in a bay that is very famous. The bay is Tapian Nauli. Various supplies for the benefit of the time are available there, from around the Gulf Tapian Nauli, the ports along the western coast, the rear area (hinterland), and even from Gujarat, India.

Sibolga port is a trade center which is always visited by traditional boats and modern ships from Malacca, such as fireboats, motorboats, sailboats, and ships of the government of Dutch/Netherlands. Besides trading with fellow residents along the west coast of Sibolga, the residents also trade with foreign merchants in Malacca, especially with traders from Gujarat and Arab countries. In 1892 the port of Padang (Emmahaven) was built by the Dutch. Also, since 1922, Belawan port on the east coast of Sumatra has increasingly been exporting goods, especially made of plants, to Deli and other 
surrounding areas. Thus all the trading and shipping activities usually carried out in the port of Sibolga are taken over by the second port (Nur, 2015, p. 2).

Sutjipto Tjiptoatmodjo writes about the coastal cities around Madura Strait and their role in relation to the countryside during the $17^{\text {th }}$ to $19^{\text {th }}$ centuries. According to Tjiptoatmodjo Sutjipto, coastal cities are located in the Madura Strait and inland areas that are interdependent but yet provide support to each other. The residents of coastal cities of Madura Strait receive routine basic goods mostly from inland or rural areas around the town's beaches, and some even from far inland (Tjiptoatmojo, 1983, pp. 16-17; Horridge, 2015, pp. 72-78; Nur, 2015, pp. 7-8).

J. Kathirithamby-Wells reveals the wisdom that is run by the port authorities at Bantam in the $16^{\text {th }}$ and $17^{\text {th }}$ centuries. The port of Banten serves as pepper export port in the Sunda Kingdom, factors that cause the height of these ports were due to the fall of Malacca to the Portuguese in 1511. Many merchants who did not want to deal with the Portuguese, they usually traded in Malacca to divert their voyage to the province, the west coast of Sumatra, the Sunda Strait, and Banten. Bantam ruler controlled the pepper plantations in the uplands of Sunda, the southern part of Lampung, Sumatra's west coast (Silebar), and the southern part of Sumatra. The Banten Sultan was famous for pepper plantations. Thus, it became the most important port on the island of Java. Banten market accommodated all kinds of merchandise and foods that could be bought at a low price (Kathirithamby-Wells, 1990, p. 107; Djoko Marihandono, 2015, p. 174).

Heather Sutherland (1989) researched the history of the port of Makassar. According to his research, the Javanese traders have been visiting this city before 1500. Then Malays from the western archipelago began to visit the waters. According to Sutherland (1989), they follow the movement of Bajau ethnic on the move at sea. In the $16^{\text {th }}$ century, under the kingdom of Goa and Tallo, there is a possibility that Makassar received foreign traders, and it became the administrative center. Local conditions coupled with advances in trade in the $16^{\text {th }}$ century proved Makassar's ability as the most effective harbor. After Malacca fell to the Portuguese, many Malacca traders moved to Makassar. It resulted in the emergence of the powerful port of Makassar as a trade center. This port was growing when Dutch merchants conquered Malacca in 1641. Makassar after being a port city in the Dutch colony in the $18^{\text {th }}$ century had still opened its ports to foreign traders to enliven the port in the trade. Wisdom is the underlying factor of growth and Makassar progress as a colonial port city in the late 19th century, so the history was an amazing rapid success in the history of the archipelago. Makassar harbor comes alive 
with activities of Chinese junks and boats cruise natives. Chinese traders enliven the port of Makassar. The trading world in Makassar had then used a coin called Chicken Currency (Sutherland, 1989, p. 106; Abdullah, 2015, p. 348).

Edward L. Poelinggomang (1991) also assessed the economic functions of Makassar. He saw protectionism and free trade in the 19thcentury a predominant feature of Makassar. It happened when the Dutch government had started protecting the trading activities in the country. It had a monopoly in the Indies as well as in Singapore. At the time Verenigde OostIndische Compagnie (VOC) Chinese merchants and sailors were allowed to visit the city of Makassar, but in the early era of the Dutch East Indies, Batavia only opened for visits because it was considered a threat to the government (Poelinggomang, 1991, pp. 238-239). In addition, Makassar has remained an important port city for commerce in Southeast Asia (Abdullah, 2015, p. 62). When English traders in Singapore implemented the policy of free trade, they easily received support and cooperation from the local merchants. They also managed to establish trade relations. British traders were enticing them to trade in Penang and Singapore. British successfully attracted more traders to Singapore. Makassar traders also traded in Singapore because the British had advantages in the economics, industrial development, and a large number of its trading fleet. It also took control of the most important commodities. The growth and development of world maritime Southeast Asian archipelago are not believable without harbors and coastal cities, such as Malacca, Penang, Batavia, Padang, Sibolga, Medan, Palembang, Jambi, and so forth. A town came after the economic surplus in the countryside (Nur, 2015, p. 17).

Frank Broeze (1989) said that the port city served other social, cultural and economic purposes besides mercantile and commercial activities. Ports occupied a higher position than in other areas in a city (urban) because these were center of economic activities. Ports in Southeast Asia contributed to the hinterland. Ports have been in contact with foreign merchants since centuries ago.

Malacca port provided full facilities so that merchants happily continue their trade activities. Emporium is a port city that is equipped with various facilities to meet the needs of traders and sailors. Such harbors were established in the 10th and the $11^{\text {th }}$ centuries in the Indian Ocean, which include Aden and Mocha in the Red Sea; Muscat, Bandar Abas, and Hormuz in the Persian Gulf; Cambay, Calicut, and Goa in the Arabian Sea; Satgaon in the bay of Bengal, Malacca in the Straits of Malacca; Khanfu in Canton; Zaiton 
and Nanking in China Sea (Reeves, Broeze, \& Mcpherson, 1989, p. 34; Nur, 2015, p. 17).

In its development, the role of the Straits of Malacca can not be separated from the port emporium's growth in the waterway or outside the waterway, such as the Arabian Sea and the Indian Ocean. Ports of emporium have a credit facility in the form of economic, warehouses, accommodation and so on. Active employers who dominated the trade were one of the characteristics of the port emporium. Ships could be purchased or rented them to carry out a trade expedition to other ports; Such trading businesses are named as Commenda traders.

Ports are very supportive trade emporium Commenda. The existence of the port along the shipping lanes and trade reduces the risk of marine accidents, as merchant ships do not have to go far away. These pull up in the port city nearby, and they carry forward to the next cities through the other vessels. They wait for the next ship to carry on the goods to a port farther. Since ancient time, the Strait of Malacca has remained crowded with carrying goods and commodities to different directions. Ships came from nearby ports and also from the remote areas, such as the Middle East, Europe, America, Africa, and other areas. Transportation of goods in the relay across the city also occurred in Southeast Asia, and Malacca became the center.

\section{Effect of Malacca Strait on Indonesia-Malaysia}

The Straits of Malacca's shipping lanes, ports and trade routes are the most popular in the world (Reid, 1995, p. 1; Marihandono, 2015, p. 127). Since ancient times the Malacca Strait region crowded with the traffic of ships between India and China. Jung-Jung China and ships in the archipelago have enlivened the Straits (Chaudhuri, 1989, p. 100). Before 1500 A.D, India and China traded silk and other material. Both countries faced issues in bringing silk from China to India by road; thus, they opted for the sea routes via the Strait of Malacca.

In the 7th century, several Sriwijaya ships were trading in the waterway. They did not only brought camphor, various types of wood, spices, such as cloves, gardamunggu, pearls, perfumes, ivory, brown rock, turtle, but also wool and cotton fabrics. The goods were exchanged for gold, silver, porcelain, silk, sugar, iron, rice, and so on (Meilink Roeloffsz, 1962, p. 14; Utomo, 2017, p. 49). The clam waters of the Strait of Malacca had the huge traffic of ships during the ancient Srivijaya (Muljana, 2008, p. 3; Utomo, 2017, p. 53) and these served Indian and Chinese economic and trade interests 
(Muljana, 2008, p. 3). Srivijaya kingdom controlled the traffic in the Strait of Malacca. In 1025, the Malacca Strait was attacked by the king of Cola in the south India; which resulted in the weakening the Sriwijaya economy (Hall, 1985, p. 23; Utomo, 2017, p. 56).

Arab traders also took an active part in shipping and trade in the Straits. Muslim traders proceeded it after the coming of Islam in the archipelago. Traders from Aceh, Jawa, Johor, Brunei, and other Islamic merchants used to gather in Malacca to sell products and buy material of their needs (Hall, 1985, p. 25). The traders from Pasai, Aceh northwest tip of Sumatra island had also been trading in the waterway and they spread Islam in some areas of Southeast Asia. Pasai was one of the kingdoms located in the waterway and the maritime. The kingdom supported the Strait of Malacca in shipping and trade between India and China (Zuhdi, 1993, p. 22).

In the 15th century, the price of spices was higher in Europe, which pushed Europeans to find the sources of spices. The Portuguese and Spaniard tried to sail to find the areas of origin of the herbs/spices. In 1511, the Portuguese arrived in Malacca and conquered the kingdom. Followed by the Netherlands, Britain, and other nations. According to Gusti Asian, in the 16th century, the port of Malacca was made by the Portuguese as a trading center and commodities, goods and services had also come from the west coast of Sumatra. The Portuguese had affected the Islam in the region because before their arrival, Islam was predominant religion practiced by merchants and sailors in the strait (Asnan, 2000, p. 43). The traders of Aceh that usually traded in Malacca were uncomfortable with the arrival of the Portuguese because of the nature of the Portuguese monopoly with the motto: Gold, Glory and, Good. They were after the triumph and development of Christian Catholic religion. Aceh was trying to expel the Portuguese in Malacca and had sent troops to the ships through the Straits of Malacca. The Strait of Malacca trade route had become both Aceh and Minangkabau for centuries. The area was familiar to them, and they had established a relationship with their other Malay brothers in the Malay Peninsula. However, the attack on the Portuguese in Malacca Aceh did not succeed because the Portuguese weaponry was much more advanced. It was a major factor, which had changed trade route to the west coast of Sumatra, namely to the ports of pepper and spices, such as Meulaboh, Barus, Sibolga, Christmas, Airbangis, Tiku, Pariaman, Padang and Bandar X. Bandar $X$ is ten cities located in the South Coast province of West Sumatra, including Tarusan, Salido, Painan, Batangkapas, Surantih, Kambang, Sungai Tunu, Hall Tuesday, Airhaji, and Indrapura (Nur, 2015, p. 23). 
In the $18^{\text {th }}$ and $19^{\text {th }}$ centuries, the countries which stood foremost in the waterway that included Malacca, Penang, Singapore and the Malay states in Riau Islands. England also paid full attention to the shipping and trade in the Straits. Various types of merchandise contained in Malacca from Aceh, Banten, Manila, Canton, Macau, and another archipelago area (Chaudhuri, 1989, p. 80). The Malacca Strait means waters which caused various nations and ethnic groups and identities to meet and unite for shipping and trading (Reid, 1995, p. 154; Hamid, 2015, p. 92).

Penang became the center of commodity items in the Malacca Strait, such as Gambir, nutmeg, cloves, black pepper, and so on (Khoo \& Lo, 1983, p. 11; Reid, 1995, p. 171). Ethnic Chinese, Malay Kedah, Malay Sumatra, and Indians came to Penang. Singapore has remained a dynamic port for India and China. Likewise for Malay traders who had come from all over the archipelago. The Malays traded in forest products, tin ore, ivory, gold, cassava, rice, and other commodities items. Hectic shipping and trade in the Strait of Malacca caused the more robbery. Thus, it became a big threat to shipping and doing trade in the Malacca Straits and even in the Southeast. The British government attempted to control the sea pirates, but it failed because the Southeast Asia region consisted of mostly local waters, seas, straits, and islands (Reid, 1989, p. 55).

The presence of Europeans in the waterway disrupted world shipping and trading that had been built by various tribes. The Dutch and British traders always applied monopolistic tricks and systems that broke down the trade network not only in financial terms but also caused great disorientation in the cultural communication (Reid, 1995, p. 172). EIC an official British company that gets the challenge of VOC (Dutch) tried to control the center of the spice to propitiate the population in certain areas. In 1784, an employee named Thomas Forrest EIC mission to Riau to seek the establishment of the British trading post in the waterway (Reid, 1995, p. 268). The place is located in Pinang island in the waters of the west coast of the Malay Peninsula. Despite political changes in Europe, the British colonial power returned to the Dutch East Indies, but England still maintained its legitimacy in the region. To strengthen his power in the waterway, England under Sir Thomas Stamford Raffles established colonies in Singapore in 1819. Through it, the United Kingdom wanted to have a major involvement in the waterway (Reid, 1995, p. 196).

Minangkabau people spread over the areas like Darek, Riau, Riau Islands, and the Malay Peninsula, in particular, the Negeri Sembilan had played a very important role in the waterway. Commodities and goods were 
taken secretly through rivers of central Alam Minangkabau into the waterway. This was done because of the tight regulatory coffee cultivation applied by the Dutch in Minangkabau. The good relationships between merchants of Minangkabau and the Strait of Malacca were going on for hundreds of years. Trade contacts also took effect on cultural and religious contacts, ranging from the trust, the influence of Hindu - Buddhism, and Islam. Several coastal areas in the Strait of Malacca embraced Islam because of contact with Muslim traders from Arabia, as Perlak, Samudra, and Pasai in Sumatra, Indonesia. Pasai is one part of the maritime, which has influenced the shipping and trade from China in the Straits (Zuhdi, 1993, p. 31). The result is the Malacca Strait into shipping lanes and strategic trade between the centers of trade and shipping in the world, especially among India, China, and Japan (Asnan, 2007, pp. 47-48). The growth of Malacca port has become possible by the supported of traders who had come from the archipelago region, Southeast Asia, Asia, and Europe (Basu, 1985, p. 3).

\section{Cultural Relations Indonesia - Malaysia}

Since ancient times, tribes living in the Strait of Malacca interacted. They also interacted with people from across the world who had come as merchants, traders, buyers and sailors. The local tribes had more frequent interactions with ethnic groups from India and China. Malay ethnic groups from mainland Peninsular Malaysia had spread to the archipelago. The ancestors of the Malays touted by experts from the area of Tonkin and Annam, land in the border area between Southeast Asia and China or area Kampuchea and Vietnam. Distribution of the ethnic Malay Archipelago who are Sumatra, Kalimantan, Sulawesi, Java, and other islands, such as the Lesser Sunda Islands. Distribution does not just stop there, but once formed tribes distribution continued even after it led to the original starting point region. Aceh and Minangkabau ethnic groups, for example, were not settled in Bukit Barisan Sumatra island, but they were nomadic and returned to the Malay Peninsular. No stranger to that, there has been an alternating current Minangkabau ethnic Malays between central Sumatra and the Malay Peninsula, particularly Negeri Sembilan.

According to Tsuyoshi Kato, Minangkabau relations between Indonesia and Malaysia Negeri Sembilan lived and survived through major rivers known as the Three Jurai, namely Batang Hari River, Indragiri River and Kampar River (Tsuyoshi, 2001, p. 377). Minangkabau people who were in Negeri Sembilan generally derived from darek region, the central region of Minangkabau, a case Sungaitarab, Sumanik, Sarilamak, Batuhampar, Mungka, 
Simalanggang, and so forth (Refisrul, 2003, pp. 79-86). Such relations can not be separated from a waterway.

The relationship between the Minangkabau and Negeri Sembilan was evidenced by the request of several people of Raja Negeri Sembilan to Pagaruyung, like King Malewar (1773), King of the Black (1795), and King Lenggang. Then nearly for two centuries, the relationship between the Minangkabau and Negeri Sembilan had disconnected because of colonialism of European nations, namely the British in Malaysia and the Netherlands in Indonesia. In 1968, the relationships were restored after the coming of Tan Sri Datuk Samad Idris to West Sumatra. The Former Minister of Culture Youth and Sports Malaysia Tanah Datar met the Mayor of Padang Akhairul Yahya, Datuk Rashid Manggis panghulu in London Mahyudin Algamar, Tanah Datar. Then Tan Sri Datuk Samad Idris returned to West Sumatra, especially Batusanggkar in 1970 to attend the Minangkabau Cultural Seminar. The results of several times visit of Tan Sri Datuk Samad Idris to West Sumatra was considered goodwill visits for the promotion of arts, awarding honors, development aid, the establishment of the twin cities, and so on (Refisrul, 2003, pp. 79-86). The Malacca Strait sea proved that it is not as a separator between Indonesia and Malaysia, but a means of unifying the two allied nations.

\section{Conclusion}

For centuries, the Malacca Strait has remained very important in the history of shipping and trade by locals and outsiders Due to its significant location in the Southeast Asia region; many nations came to it, some passed through it, some stayed and traded, some conquered it, and then they were defeated by the locals. The trading nations and groups included Arabs, Indians, Chinese, Madagascar, European, American, Minangkabau, Bugis, Javanese, Balinese, and so forth. The strait of Malacca as a waterway and center of economic power has seen many ups and downs because of the economic impact and the impact of the arrival of foreign nations. The Malacca Strait region offered places safe anchorage for merchant vessels, such as Malacca, Singapore, Pasai, Aceh, Penang, and a river estuary on the east coast of Sumatra. Among these are Kampar river mouths, estuaries Indragiri river, Batang Hari river mouth, the mouth of the Musi river, and so forth.

From the $17^{\text {th }}$ to $19^{\text {th }}$ century, these rivers could be navigated to the upstream, especially Palembang, Jambi, and Minangkabau. The Malacca Strait maritime world is built over the centuries. It has created a culture of interethnic communication; the waters of the Strait of Malacca are not the separator 
between Indonesia and Malaysia, but the interlocutors between the two allied nations.

\section{References}

Abdullah, T. (2015). Sejarah kebudayaan Islam Indonesia sastra dan seni Jilid 4. Jakarta: Direktorat Sejarah, Direktorat Jenderal Kebudayaan, Kementerian Pendidikan dan Kebudayaan RI.

Asnan, G. (2007). Dunia maritim Pantai Barat Sumatra. Yogyakarta: Ombak.

Basu, D. K. (1985). The rise and growth of the colonial port cities in Asia. Berkeley: University Press of America.

Broeze, F. (Ed.). (1989). Brides of the sea, port cities of asia from the $16^{\text {th }}-20^{\text {th }}$ centuries. Kensington: New South Wales University Press.

Chaudhuri, K. N. (1989). Trade and civilisation in the Indian Ocean, an economic history from the rise of Islam to 1750. Cambridge: Cambridge University Press.

Hall, K. R. (1985). Maritime trade and state development in early Southeast Asia. Honolulu: University of Hawai Press.

Hamid, A. R. (2015). Sejarah maritim Indonesia. Yogyakarta: Ombak.

Horridge, A. (2015). Perahu layar tradisional Nusantara. Yogyakarta: Ombak.

Kathirithamby-Wells, J. (1990). Banten: A West Indonesian port and polity during the sixteenth and seventeenth centuries. In J. KathirithambyWells \& J. Villiers (Eds.). The Southeast Asian port and polity: Rise and demise. Singapore: Singapore University Press.

Khoo, G., \& Lo, D. (1983). Asia dalam perubahan sejarah Tenggara, Selatan, dan Timur Asia. Kuala Lumpur: Heinemann Educational Books (Asia).

Marihandono, D. (2015). Rempah, jalur rempah, dan dinamika masyarakat Nusantara. Jakarta: Direktorat Sejarah, Direktorat Jenderal Kebudayaan, Kementerian Pendidikan dan Kebudayaan RI.

Meilink-Roelofsz, M. A. P. (1962). Asian trade and European influence in the Indonesian archipelago between 1500 and about 1630. Dordrecht: Springer Netherlands.

Muljana, S. (2008). Sriwijaya. Yogyakarta: LKIS Pelangi Aksara.

Nur, M. (2015). Bandar Sibolga di Pantai Barat Sumatera pada abad ke-19 sampai pertengahan abad ke-20. Padang: BPNB.

Poelinggoman, E. L. (1991). Proteksi dan perdagangan bebas, kajian tentang perdagangan Makassar pada abad ke-19. Ph.D. thesis, Centrale Huisdrukkrij VU, Vrije Universiteit, Amsterdam, The Netherlands.

Reeves, P., Broeze, F., \& Mcpherson, K. (1989). Studying the Asian port city. In F. Broeze (Ed.). Brides of the sea port cities of Asia from the 16th-20th 
centuries (pp. 29-53). Kensington-New South Wales: New South Wales University Press.

Refisrul. (2015). Minangkabau dan Negeri Sembilan: Sistem Pasukuan di Nagari Pagaruyung dan Negeri Sembilan Darul Khusus Malaysia. Padang: BPSNT Padang Press.

Reid, A. (1989). The organisation of production in the pre-colonial Southeast Asian port city. In F. Broeze (Ed.). Brides of the sea port cities of Asia from the 16th-20th centuries (pp. 54-74). Kensington-New South Wales: New South Wales University Press.

Reid, A. (1995). Sumatra tempo doeloe dari Marco Polo sampai Tan Malaka. New York: Oxford University Press.

Sutherland, H. (1989). Eastern emporium and company town: Trade and society in eighteenth century Makassar. In F. Broeze (Ed.). Brides of the sea port cities of Asia from the 16th-20th centuries (pp. 97-128). Kensington-New South Wales: New South Wales University Press.

Tsuyoshi, K. (2001). Sumatra Barat, Kuantan dan Negeri Sembilan dalam perspektif sejarah. In E. Sedyawati \& S. Zuhdi (Eds.), Arung Samudera: Persembahan memperingati sembilan windu A. B. Lapian (pp. 377-390). Depok: Pusat Penelitian Kemasyarakatan dan Budaya, Lembaga Penelitian Universitas Indonesia.

Utomo, B. B. (2017). Kebudayaan dari Swarnadwipa hingga Sumatra. In S. Sugiharta (Ed.), Sumatera silang budaya konstelasi nilai-nilai historis, arkeologis, dan antropologis serta upaya pelestarian cagar budaya. Batusangkar: BPCB Batusangkar.

Zuhdi, S. (1993). Pasai kota pelabuhan jalan sutra: Kumpulan makalah diskusi. Jakarta: Departemen Pendidikan dan Kebudayaan, Direktorat Jenderal Kebudayaan, Direktorat Sejarah dan Nilai Tradisional, Proyek Inventarisasi dan Dokumentasi Sejarah Nasional.

Date Received: 15 November 2017 Date of acceptance: 15 April 2018 